\title{
Pemanfaatan Limbah Biji Pepaya menjadi Olahan Kopi di Desa Donomulyo, Kulon Progo
}

\author{
Calvindo Aldi Sutanto, Trivena Frisdayanti, Rosiana, Albertus Jiwo Kunadi Putra, Fransisca Nadita Laura Krisna, Nadia Sastrivia Eka \\ Christy, Ari Jeremy Williams Situmeang, Lauw, Vanessa Irene Natalie, Yohanes Krisostomus Farih Lintang Jati ${ }^{9}$, Budianto Parulian \\ Lumbantoruan, Putri Nastiti \\ Universitas Atma Jaya Yogyakarta, Jl. Babarsari No. 44, Janti, Caturtunggal, Kec. Depok, Kabupaten Sleman, Daerah Istimewa \\ Yogyakarta $^{1}$ \\ Email: putri.nastiti@uajy.ac.id
}

Received: June 16, 2021; Revised: -; Accepted for Publication: March 23, 2023; Published: March 28, 2023

\begin{abstract}
Abstrak - Pepaya is a type of fruit that is very common in Indonesia. Besides being easy to find, pepaya, the fruit of a million benefits, is also cheap. So far, pepaya is often eaten directly or processed simply so that it leaves the skin and seeds. Pepaya seeds are not used and end up in landfills so that innovation is needed to have a sale value. This journal aims to use pepaya seed waste, which is converted into coffee, to increase the income of Donomulyo village. This is in line with the increasing trend of coffee lately. The process of making coffee goes through several stages, namely cleaning the coffee beans, drying, roasting, and refining the coffee beans.
\end{abstract}

Keyword - papaya seed, coffee, inovation

\begin{abstract}
Abstrak - Pepaya merupakan salah satu jenis buah yang sangat umum sekali ditemukan di Indonesia. Selain mudah ditemukan, pepaya yang memiliki berjuta manfaat ini juga tergolong buah yang cukup murah. Selama ini pepaya sering dikonsumsi dengan dimakan langsung atau diolah sederhana sehingga menyisakan kulit dan bijinya. Biji pepaya yang tidak dimanfaatkan akan berakhir di tempat pembuangan sampah. Padahal biji papaya juga dapat dimanfaatkan untuk berbagai hal. Walaupun demikian perlu adanya inovasi agar biji papaya dapat memiliki nilai jual. Tujuan dari jurnal ini adalah untuk mempublikasikan pemanfaatan limbah biji pepaya sebagai pengganti kopi sehingga dapat meningkatkan pendapatan desa Donomulyo. Hal ini selaras dengan trend kopi yang sedang meningkat akhir-akhir ini. Proses pembuatan kopi dari biji papaya melalui beberapa tahap yaitu pembersihan biji pepaya, pengeringan, penyangraian, dan penghalusan biji papaya menjadi bubuk kopi pepaya.
\end{abstract}

Kata Kunci — biji pepaya, kopi, inovasi

\section{Pendahuluan}

Di benua Amerika, tepatnya Meksiko merupakan asal muasal dari tanaman Pepaya (Pepaya Carica). Tanaman ini sudah tersebar di seluruh dunia sehingga dewasa ini cukup mudah menemukan tanaman pepaya khususnya di daerah tropis. Pepaya merupakan salah satu jenis buah yang umum ditemukan di Indonesia. Pepaya merupakan salah satu jenis buah berpotensi di Indonesia karena dapat dikembangkan guna menyejahterakan masyarakat. Nyatanya ada banyak sekali olahan hasil papaya yang diperjual-belikan. Hal ini terjadi karena tanaman ini tumbuh dengan mudah dan menyebar hampir di seluruh Indonesia. Selain Indonesia dan Meksiko, ada beberapa negara lain yang juga menghasilkan buah ini seperti Kosta Rika, Republik Dominika, Puerto Rika, Brazil, dan lain-lain [1]. Aroma dan tekstur buah pepaya banyak disukai oleh banyak orang. Banyak orang yang tertarik dengan buah pepaya karena buah ini memiliki banyak manfaat seperti memperlancar buang air besar, kandungan vitamin $\mathrm{C}$ yang berlimpah sehingga dapat meningkatkan sistem kekebalan tubuh. Tak hanya pada buahnya, manfaat dari tanaman ini dapat kita temukan pada bagian lainnya seperti batang, daun, bahkan sampai akarnya. Selain manfaat yang terkandung di dalam tanaman ini, buah ini memiliki harga yang cukup terjangkau dan sangat mudah di temukan di sekitar kita[2].

Masyarakat Desa Donomulyo sendiri, memiliki perkebunan pepaya sendiri di sekitar rumah. Namun, pemanfaatannya sendiri masih belum bervariasi. Biasanya pepaya tersebut akan dijual kembali ketika sudah matang. Belum banyak masyarakat desa yang mengetahui olahan pepaya, terutama untuk biji pepaya yang sering dibuang dan menjadi limbah di sekitar rumah. Hal ini dikarenakan masyarakat juga belum mengetahui manfaat dari biji pepaya tersebut.

Seiring penyebaran dan pertumbuhannya yang mudah, konsumsinya juga kian meningkat. Namun di sisi lain limbah dari buah pepaya juga akan meningkat secara langsung. Limbah tersebut adalah biji buah pepaya. Biji pepaya menjadi limbah karena tidak dapat dikonsumsi secara langsung dan menimbulkan rasa getir ketika tidak sengaja tergigit. Namun, dibalik limbah biji pepaya yang sering dibuang begitu saja, terdapat manfaat yang jarang diketahui oleh masyarakat. Salah satunya yaitu memanfaatkan limbah biji pepaya menjadi olahan kopi biji papaya [3]. Pemanfaatan limbah biji pepaya dapat menjadi altirnatif pengganti biji kopi. Karena biji pepaya mengandung alkaloid, steroid, minyak atsiri, karbohidrat dalam jumlah kecil, air, protein dan lemak. Selain itu kandungan alkaloid, flavonoid, tannin, saponi anthraquinones dan anthocyanosides telah terbukti secara signifikan dapat menurunkan kadar kolesterol serta berfungsi sebagai antioksidan yang ada didalam darah [3]. Jadi, 
kandungan yang terdapat pada biji pepaya juga bermanfaat bagi kesehatan tubuh.

Limbah biji pepaya selama ini hanya dibuang begitu saja karena masyarakat belum mengetahui manfaat dan cara pengolahannya. Melalui program KKN 79 ini, limbah biji pepaya tersebut akan diolah menjadi kopi biji pepaya yang diharapkan dapat memberi nilai tambah bagi olahan pepaya serta masyarakat Desa Donomulyo, Biji papaya juga tidak kalah manfaatnya dibandingkan dengan daging buah papaya. Biji papaya juga mengandung alkaloid yang dapat mempercepat metabolism karena berefek sitotoksik [4]. Hal tersebut dapat membantu orang yang sedang mengalami konstipasi. Kecamatan Nanggulan, Kabupaten Kulon Progo. Olahan kopi biji pepaya juga dapat menjadi potensi bagi masyarakat Desa Donomulyo yang memiliki nilai ekonomi dan dapat menjadi sumber pendapatan masyarakat Desa Donomulyo. Selain itu, dengan adanya program pengolahan limbah biji pepaya menjadi kopi biji pepaya, masyarakat memiliki pengetahuan baru yang bermanfaat untuk pertumbuhan kreativitas serta inovasi penduduk desa. Sehingga diharapkan program ini dapat menjadi salah satu sumber penggerak perekonomian Desa Donomulyo, Kecamatan Nanggulan, Kabupaten Kulon Progo.

\section{Metode Pengabdian}

\section{A. Metode Kegiatan}

Metode yang digunakan dalam kegiatan ini adalah melalui penyuluhan. Penyuluhan sendiri adalah proses menyebarluaskan informasi yang berkaitan dengan upaya perbaikkan cara-cara dalam bertani, demi meningkatkan kesejahteraan dan pendapatan [5]. Kuliah Kerja Nyata 79 dilakukan secara daring dikarenakan oleh pandemi virus Corona. Pelaksanaan kegiatan Kuliah Kerja Nyata ini dilaksanakan dengan menggunakan berbagai macam platform untuk berkomunikasi satu sama lain, seperti Microsoft Teams dan Whatsapp.

\section{B. Sumber Data}

Data yang akan digunakan dalam penelitian ini adalah data sekunder yang diperoleh melalui jurnal-jurnal terkait. Selain itu, data juga diperoleh melalui situs-situs instansi pemerintah Desa Donomulyo yang berhubungan dengan data kependudukan seperti luas wilayah, jumlah penduduk Desa Donomulyo, mata pencaharian utama masyarakat desa dan potensi-potensi yang ada di Desa Donomulyo yang masih belum dimanfaatkan secara maksimal oleh masyarakat. Selain jurnal, Penulis juga menggunakan sumber berupa $e$ book (buku elektronoik) dan situs web yang berkaitan.

\section{Teknik Pengambilan data}

Teknik Pengumpulan data yang penulis gunakan adalah teknik observasi dan studi pustaka. Teknik Obervasi merupakan metode pengumpulan data, dimana peneliti melakukan pengamatan atau meneliti langsung objek mengenai aktivitas yang berhubungan dengan penelitian [6]. Sedangkan studi pustaka dipraktekkan dengan cara membaca jurnal-jurnal penelitian sebelumnya yang saling berkaitan dengan penelitian.

\section{Analisis Data}

Proses analisis data akan dilakukan dengan cara membaca, mempelajari, dan membandingkan data serta sumber data yang sebelumnya sudah ditentukan agar sesuai atau valid dengan penelitian. Dari proses analisis data akan terbentuk sebuah infomasi yang dapat menjadi solusi yang tepat atas permasalahan dan sesuai dengan tujuan dari penelitian yaitu memaksimalkan potensi desa berupa limbah biji pepaya menjadi kopi biji pepaya di Desa Donomulyo.

\section{E. Pengambilan Sampel}

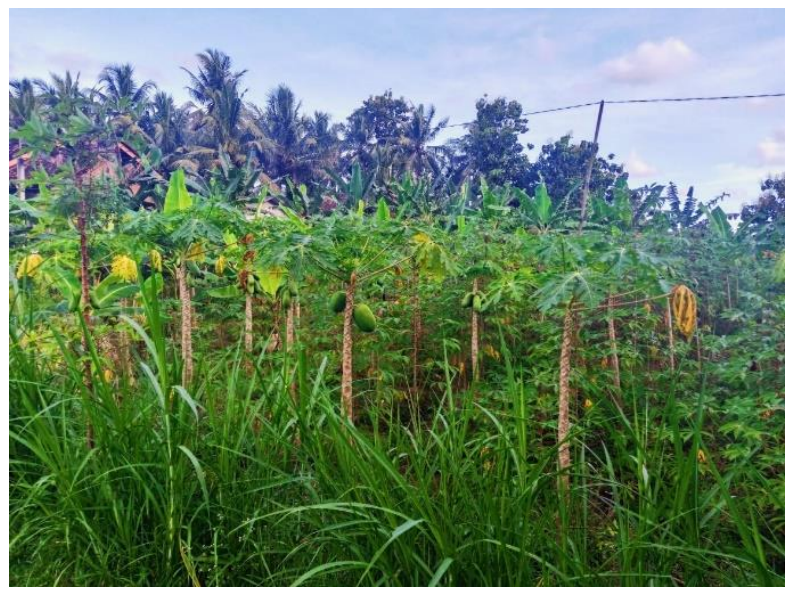

Gambar 1. Tanaman Pohon pepaya yang ada di lokasi desa Donomulyo, Kulon Progo

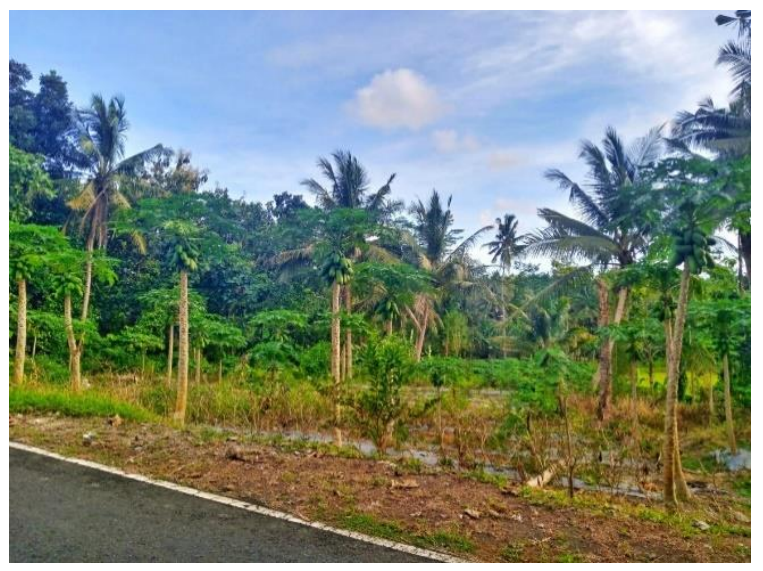

Gambar 2. Tanaman Pohon pepaya yang ada di lokasi desa Donomulyo, Kulon Progo 


\section{HASIL DAN PEMBAHAAN}

\section{A. Hasil}

Penulisan jurnal dilakukan untuk mengetahui bagaimana cara mengolah limbah biji pepaya yang jarang diketahui masyarakat. Selama ini biji pepaya hanya dibuang oleh masyarakat yang mengkonsumsi buah pepaya, karena dianggap tidak memiliki manfaat. Namun, dengan ditulisnya jurnal ini, akan dijelaskan manfaat yang terkandung dalam biji pepaya dan contoh olahan dari limbah biji pepaya.

\section{B. Pembahasan}

Desa Donomulyo terletak di Kecamatan Nanggulan, Kabupaten Kulon Progo, Yogyakarta. Desa Donomulyo memiliki luas $9,70 \mathrm{Km}^{2}$ dengan 10 padukukan yang ada didalamnya [7]. Sebagian besar masyarakat bekerja sebagai petani dan bertani menjadi mata pencaharian utama masyarakat Desa Donomulyo. Usaha lainnya yang digeluti oleh masyarakat desa yaitu peternak sapi, kambing, dan ayam, membuka usaha toko kelontong, beberapa memiliki perkebunan kelapa dan pepaya di sekitar rumah. Bertani dan berkebun menjadi usaha yang paling banyak digeluti oleh masyarakat Desa Donomulyo, dikarenakan tanah yang ada di desa dapat dikatakan subur, sehingga masyarakat memanfaatkannya untuk memperoleh penghasilan.

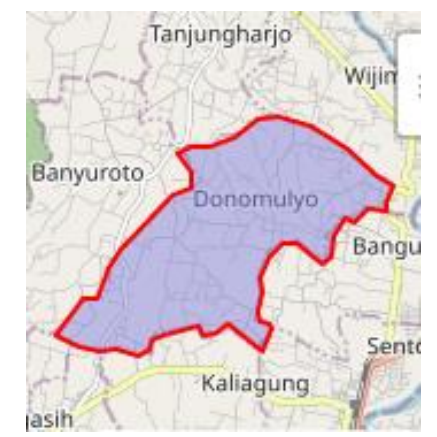

Sumber: http://donomulyo-kulonprogo.desa.id/

Gambar 3. Lokasi Desa Donomulyo

Desa Donomulyo berada pada posisi yang strategis dengan beberapa desa lainnya. Selain itu jarak antara desa dan Kota Yogyakarta yang relatif dekat memudahkan masyarakat membawa hasil pertaniannya dari desa ke kota untuk dijual kembali.

Dengan ukuran wilayah yang cukup luas untuk Desa Donomulyo, masih banyak potensi-potensi yang bermanfaat bagi masyarakat agar terus perekonomian desa dapat terus berkembang. Salah satunya yaitu dengan cara mengolah limbah biji pepaya menjadi kopi biji pepaya. Berikut merupakan cara pengolahan limbah biji pepaya tersebut.

\section{- Langkah Pengolahan Limbah Biji Pepaya}

Dalam pembuatan kopi biji pepaya terdapat beberapa proses yang harus dilakukan. Bagian pertama adalah mempersiapkan alat dan bahan [3]. Dalam rangka pengolahan kopi biji pepaya secara sederhana untuk mempermudah masyarakat desa dan meminimalkan biaya produksi maka alat yang digunakan juga sederhana yaitu :

- Ember, sebagai wadah untuk mencuci biji pepaya

- Nampan, sebagai wadah untuk mentiriskan biji pepaya setelah dicuci

- Alat penggorengan sebagai pengganti mesin roasting

- Penumbuk atau blender untuk menghaluskan biji pepaya

Langkah pembuatannya sebagai berikut

- Siapkan limbah biji pepaya

- Cuci dan ilas biji pepaya hingga bersih dari sisa-sisa daging buahnya dan tiriskan

- Jemur kurang lebih selama 2 hari dibawah sinar matahari untuk mengurangi kadar air dalam biji pepaya

- Panggang biji pepaya yang sudah kering selama 15 menit untuk memastikan biji pepaya sudah benarbenar kering

- Sangrai biji pepaya dalam hingga berubah warna dan mengeluarkan aroma

- Tumbuk biji pepaya yang telah jadi menjadi butiran halus seperti kopi pada umumnya

- Untuk mendapatkan hasil yang lebih baik, biji pepaya yang sudah ditumbuk dapat di ayak, sehingga biji pepaya bisa lebih halus lagi dan tidak membuat ampas yang terlalu kasar saat akan diminum.

Proses pengeringan sangat penting dalam proses pembuatan kopi biji pepaya karena akan mempengaruhi daya simpan dari kopi tersebut. Jika kadar airnya tinggi maka usia simpan dari kopi biji pepaya juga akan singkat. Selain itu, proses roasting juga salah satu kunci utama dalam pembuatan kopi biji pepaya. Dalam proses roasting, aroma dan cita rasa biji pepaya akan keluar. Pada proses ini biji pepaya akan mengalami perubahan dari segi struktur dan beratnya yang akan menyusut. Lamanya roasting juga berpengaruh terhadap kandungan antioksidan dalam biji pepaya. Oleh karena itu, proses roasting hanya dilakukan kurang lebih 10-15 menit.

\section{- Variasi dan Inovasi}

Rasa dari olahan limbah biji pepaya menjadi kopi biji pepaya belum tentu dapat diterima oleh semua masyarakat, 
karena pasti akan berbeda dari rasa asli biji kopi.Untuk menambah cita rasa pada kopi biji pepaya, olahan tersebut daoat ditambahkan bubuk coklat dan bubuk jahe [8].

Inovasi lain dari olahan limbah biji pepaya:

Selain diolah menjadi kopi, limbah biji pepaya juga dapat diolah menjadi permen. Permen adalah jenis gula-gula (confectionary) yang diolah dengan cara mencairkan gula dalam air [8]. Olahan limbah biji pepaya sebagai permen dapat memberi rasa yang lebih manis dibandingkan kopi biji pepaya. Selain itu, cara pembuatannya juga dapat dikatakan mudah, karena hanya memerlukan alat dan bahan yang sederhana. Olahan permen dari limbah biji pepaya, cara pembuatannya akan dijelaskan dengan langkah-langkah sebagai berikut :

Alat dan bahan yang digunakan :

- Buah pepaya yang sudah matang

- Siapkan Ember atau baskom sebagai wadah pepaya dan bijinya

- Wadah untuk menyimpan biji yang sudah di pisahkan dari daging pepaya

- Pisau untuk memotong pepaya dan sendok untuk memisahkan biji

- Kuali untuk meroasting biji pepaya

- Panci untuk memasak permen

- Blender atau penumbuh biji pepaya

- Cetakan

- Gula merah atau gula putih

Langkah pembuatan bubuk biji pepaya :

- $\quad$ Siapkan pepaya yang sudah masak atau matang

- $\quad$ Potong buah pepaya dan pisahkan biji dari daging buah pepaya

- Cuci biji pepaya hingga bersih, kemudiah jemur dibawah sinar matahari

- $\quad$ Setelah kering, sangrai biji pepaya hingga beraroma khas

- Tumbuk atau blender biji pepaya hingga halus

Langkah membuat permen biji pepaya :

- Siapkan panci yang sudah diisi dengan sedikit air

- Nyalakan kompor

- Rebus air hingga mendidih

- Masukan gula merah atau gula putih secukupnya kedalam panci

- Aduk pelan hingga gula larut dalam air dan mengental

- Tambahkan bubuk biji pepaya secukupnya ke dalam panci

- Aduk hingga gula dan bubuk biji pepaya tercampur

- Matikan kompor
- Masukan adonan permen ke dalam cetakan yang sudah disediakan

- Tunggu hingga adonan dingin dan mengeras

- Keluarkan permen dari cetakan

- $\quad$ Permen biji pepaya siap dikonsumsi

Inovasi pengolahan limbah biji pepaya menjadi permen biij pepayajuga dapat dimanfaatkan masyarakat desa sebagai salah satu potensi desa yang bisa dikembangkan untuk membangun Desa Donomulyo, Kecamatan Nanggulan, Kabupaten Kulon Progo. Pentingnya inovasi dalam membangun usaha yang memanfaatkan potensi desa adalah untuk membuat perbedaan dengan membuat sesuatu yang baru dan berbeda dari produk yang sudah ada, atau menambah sesuatu yang menarik terhadap produk yang sudah ada [9].

Manfaat dari kegiatan ini yaitu menambah wawasan masyarakat Desa Donomulyo mengenai pengolahan limbah biji pepaya. Tidak hanya bermanfaat bagi perekonomian karena hasil olahan dapat dibuat menjadi usaha untuk menambah pendapatan masyarakat, limbah biji pepaya juga bermanfaat untuk Kesehatan.

Masyarakat Desa Donomulyo dapat memaksimalkan potensi yang ada di desa baik potensi fisik yang mencakup tanah, air, cuaca dan ternak, maupun potensi nonfisik seperti kegiatan gotong royong yang sering dilakukan masyarakat desa [10]. Seperti halnya dalam memaksimalkan pengolahan limbah biji papaya ini agar menjadi salah satu potensi desa yang dapat membangun kesejahteraan masyarakat desa ke taraf yang lebih baik lagi.

\section{KESIMPULAN}

Berdasarkan penulisan mengenai olahan limbah biji pepaya. Dapat ditarik kesimpulan bahwa limbah biji pepaya memiliki manfaat baik bagi kesehatan maupun untuk meningkatkan nilai ekonomi. Biji pepaya dapat diolah menjadi kopi dan permen, dengan adanya inovasi ini diharapkan dapat menambah pengetahuan masyarakat. Desa Donomulyo. Terutama bagi masyarakat yang memiliki kebun pepaya, selain buahnya yang dapat dijual, masyarakat juga dapat memanfaatkan bijinya sebagai produk olahan yang memiliki nilai jual.

\section{UCAPAN TERIMAKASIH}

Penulis mengucapkan terimakasih kepada pihak-pihak yang terlibat dalam penulisan jurnal. Terutama kepada masyarakat Desa Donomulyo, Kecamatan Nanggulan, Kabupaten Kulon Progo. Karena telah menjadi objek dalam penelitian ini. Diharapkan penelitian ini bermanfaat bagi masyarakat Desa Donomulyo dan masyarakat luas. 


\section{DAFTAR PUSTAKA}

[1] Warisno. 2003. Budi Daya Pepaya. Yogyakarta: Penerbit Kanisius

[2] N. Ramadhana, "Identifikasi Potensi Lokal Pada Tumbuhan Biji Pepaya (Carica Papaya) Sebagai Obat Tradisional Masyarakat Di Kecamatan Banggae Timur," Saintifik, vol. 1, no. 2, pp. 95-102, 2018, doi: 10.31605/saintifik.v1i2.88.

[3] N. A. Khairi, N. S. Rhamadhia, and T. Juwitaningtyas, "Pelatihan pembuatan kopi biji pepaya sebagai upaya pemanfaatan limbah industri di Desa Tirtonirmolo, Kasihan, Bantul," Seminar Nasional Hasil Pengabdian kepada Masyarakat Universitas Ahmad Dahlan, no. September, pp. 335340, 2019.

[4] Satriyasa, B. K. \& Pangkahila, W. I. 2010. "Fraksi Heksan dan fraksi Metanol Ekstrak Biji Pepaya Muda Menghambat Spermatogonia Mencit (Mus Musculus) Jantan”. Jurnal Veteriner. 11 (1): 36-4

[5] T. Mardikanto, "Ilmu Penyuluhan Pembangunan," Journal of Chemical Information and Modeling, pp. 1-17, 2007.

[6] A. M. Sari, "Desa Pada Kabaputen Pringsewu Berbasis Web," Asih Mekar Sari Jurusan Sistem Informasi, Sekolah Tinggi Manajemen dan Informatika STMIK Pringsewu Lampung, pp. 1-8, 2013.

[7] Kabupaten Nanggulan, "MONOGRAFI NANGGULAN,"

https://nanggulan.kulonprogokab.go.id, 2019. https://nanggulan.kulonprogokab.go.id/detil/428/mo nografi\# (accessed May 28, 2021).

[8] T. Pangesti, I. N. Fitriani, F. Ekaputra, and A. Hermawan, "Sweet Papaya Seed Candy" Antibacterial," Pelita, vol. VIII, no. Agustus, pp. 156-163, 2013.

[9] I. Nursetiawan, "Strategi Pengembangan Desa Mandiri Melalui Inovasi Bumdes," MODERAT: Jurnal Ilmiah Ilmu Pemerintahan, vol. 4, no. 2, pp. 72-81, 2018.

[10] E. Setyadi, Optimalisasi potensi desa di Indonesia. Jakarta: PT. Grasindo, 2019. [Online]. Available: https://books.google.co.id/books?hl=id\&lr=\&id=Ki _GDwAAQBAJ\&oi=fnd\&pg=PP1\&dq=manfaat+bi ji+pepaya+bagi+potensi+desa\&ots $=$ ohdV2FKoXm \&sig=GCfdDH5NOIriS--

WY8fMawHkPVk\&redir_esc $=\mathrm{y} \# \mathrm{v}=$ onepage $\& \mathrm{q} \& \mathrm{f}=$ false

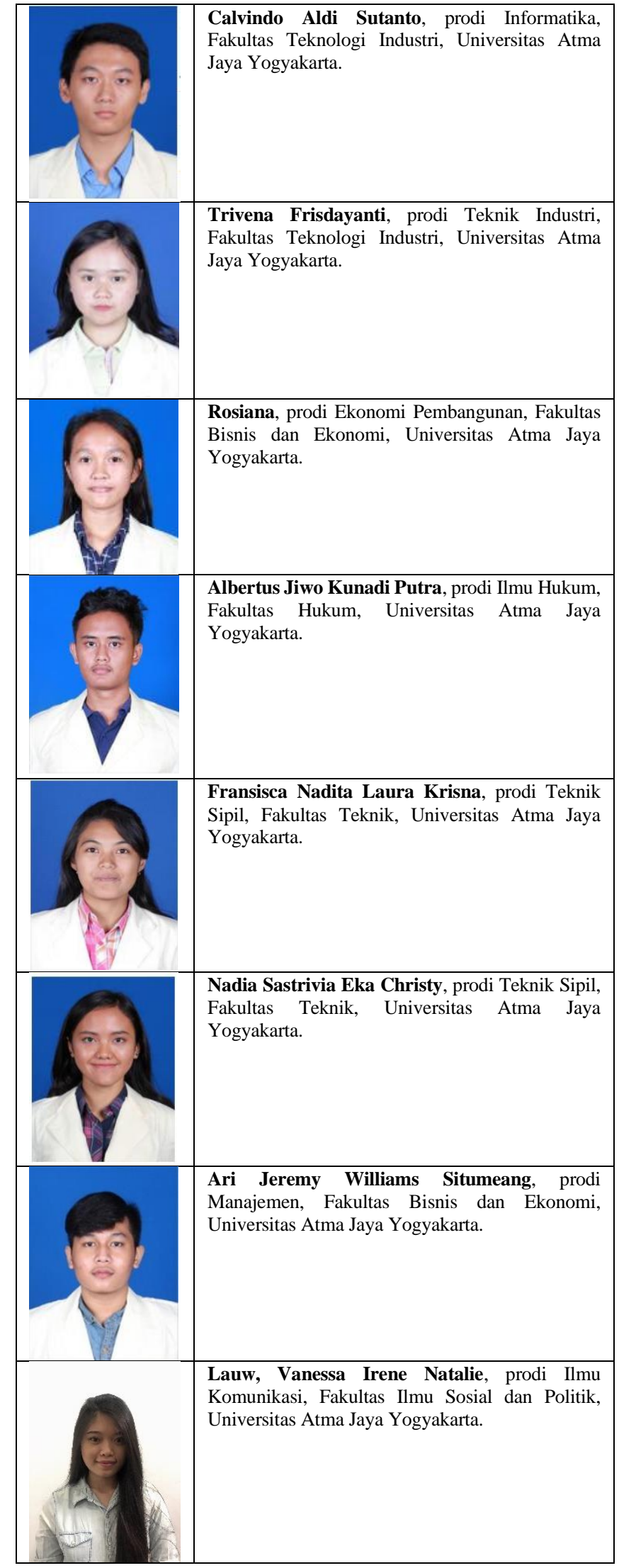




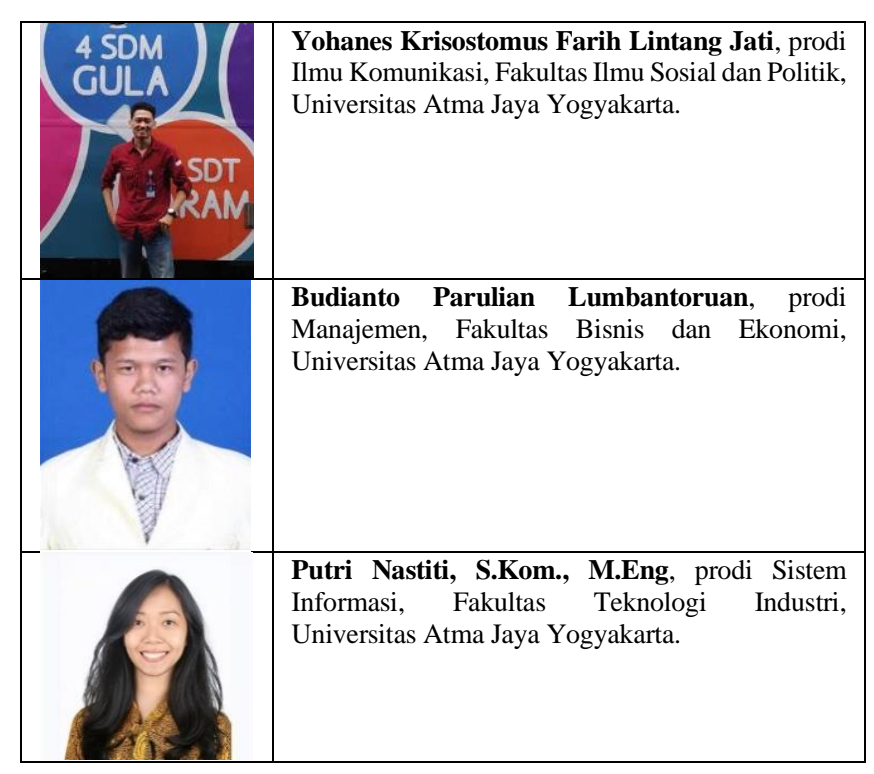

